\title{
Increased frequency of micronuclei in the lymphocytes of patients chronically infected with hepatitis B or hepatitis C virus
}

\author{
Samantha Therezinha Almeida Pereira Leite ${ }^{1}$, Marilene Borges da Silva ${ }^{2}$, Marco Andrey Pepato ${ }^{1}$, \\ Francisco José Dutra Souto ${ }^{1}$, Raquel Alves dos Santos ${ }^{3}$, Carmen Lucia Bassi-Branco ${ }^{1 /+}$ \\ ${ }^{1}$ Faculdade de Medicina ${ }^{2}$ Instituto de Biociências, Universidade Federal de Mato Grosso, Cuiabá, MT, Brasil \\ ${ }^{3}$ Universidade de Franca, Franca, SP, Brasil
}

In this study, we analysed the frequency of micronuclei (MN), nucleoplasmic bridges (NPBS) and nuclear buds (NBUDs) and evaluated mutagen-induced sensitivity in the lymphocytes of patients chronically infected with hepatitis $B$ virus (HBV) or hepatitis C virus (HCV). In total, 49 patients with chronic viral hepatitis (28 HBV-infected and $21 \mathrm{HCV}$-infected patients) and 33 healthy, non-infected blood donor controls were investigated. The frequencies (\%o) of $M N$, NPBs and NBUDs in the controls were $4.41 \pm 2.15,1.15 \pm 0.97$ and $2.98 \pm 1.31$, respectively. The frequencies of $M N$ and NPBs were significantly increased $(p<0.0001)$ in the patient group $(7.01 \pm 3.23$ and $2.76 \pm 2.08$, respectively) compared with the control group. When considered separately, the HBV-infected patients $(7.18 \pm 3.57)$ and $H C V$-infected patients $(3.27 \pm 2.40)$ each had greater numbers of MN than did the controls $(p<0.0001)$. The HCVinfected patients displayed high numbers of NPBS (2.09 \pm 1.33$)$ and NBUDs $(4.38 \pm 3.28)$, but only the HBV-infected patients exhibited a significant difference (NPBs $=3.27 \pm 2.40, p<0.0001$ and NBUDs $=4.71 \pm 2.79, p=0.03)$ in comparison with the controls. Similar results were obtained for males, but not for females, when all patients or the $H B V$-infected group was compared with the controls. The lymphocytes of the infected patients did not exhibit sensitivity to mutagen in comparison with the lymphocytes of the controls $(p=0.06)$. These results showed that the lymphocytes of patients who were chronically infected with HBV or HCV presented greater chromosomal instability.

Key words: hepatitis B - hepatitis C - lymphocytes - micronucleus

Hepatitis B virus (HBV) and hepatitis C virus (HCV) infections affect millions of individuals worldwide. Approximately $10-15 \%$ of $\mathrm{HBV}$-infected patients and 70 $80 \%$ of $\mathrm{HCV}$-infected patients develop the chronic form of their respective diseases. The primary problem associated with persistent HBV and HCV infections is the development and progression of liver disease, which ranges in severity from minimal lesions throughout the liver parenchyma to severe fibrosis, cirrhosis and hepatocellular carcinoma (HCC) (Szabó et al. 2004).

Both HBV and HCV may promote potentially mutagenic cellular processes, such as integration into the host DNA (in the case of HBV) and the generation of oxidative stress as a consequence the immune response (Farinati et al. 1995, Bartsch \& Nair 2004, Saigo et al. 2008, Sung et al. 2012).

The mutagenic effects of HBV and HCV infections are visible in hepatocytes and lymphocytes, as demonstrated by the presence of the oxidative promutagenic DNA lesion 8-oxo-7,8-dihydro-2'-deoxyguanosine (8-oxodG), which is primarily found in the lymphocytes of HCVinfected patients (Hagen et al. 1994, Farinati et al. 1995, 1999, Cardin et al. 2001). In addition, the leukocytes of $\mathrm{HCV}$-infected patients and HBV-infected patients have

doi: 10.1590/0074-0276140183

Financial support: CNPq, CAPES (to STAPL and CLB-B), FAPEMAT (737379/2008)

+ Corresponding author: carmenlubassi@gmail.com

Received 2 April 2013

Accepted 11 October 2013 been demonstrated to exhibit increased chromosomal instability (Machida et al. 2010).

The DNA damage response (DDR) includes various downstream pathways that coordinate cell cycle arrest with the repair of damaged DNA. Alternatively, the DDR can mediate the clearance of affected cells that are beyond repair through apoptosis or senescence (Heijink et al. 2013). Cells that are inefficient in these mechanisms generally exhibit higher sensitivity to mutagenic agents and it has been suggested that these cells may be preferentially selected during tumour development (Jackson $\&$ Bartek 2009). The in vitro mutagen sensitivity assay in lymphocytes has been used to examine the individual response to mutagen exposure because the cells of individuals with suboptimal DNA repair capacities are predicted to accumulate higher levels of DNA damage than those of individuals with more efficient DNA lesion repair (Wu et al. 2007). However, although evidence suggests that chronic HCV and HBV infections contribute to the development of HCC in addition to lymphoproliferative diseases (Zuckerman et al. 1997, Huang et al. 2012), few studies have investigated the mutagen sensitivity of the lymphocytes of patients that are chronically infected with HBV or HCV (Wu et al. 1998).

In this study, we compared the frequencies of micronuclei (MN), nucleoplasmic bridges (NPBs) and nuclear buds (NBUDs) in the lymphocytes of patients chronically infected with HBV or HCV with the corresponding frequencies in non-infected individuals. We employed a doxorubicin (DXR)-based mutagenesis assay to investigate whether the mutagen sensitivity of these patients' lymphocytes was increased. 


\section{SUBJECTS, MATERIALS AND METHODS}

Study population - In total, 49 patients with chronic viral hepatitis, consisting of $28 \mathrm{HBV}$-infected patients and 21 HCV-infected patients, and 33 healthy, non-infected controls were included in the study. The patients were recruited from the Clinic of Infectious Diseases of Julio Muller Hospital (Federal University of Mato Grosso, Cuiabá, state of Mato Grosso, Central-West Brazil). Chronic HBV infection was confirmed by persistent HBV surface antigenemia lasting more than six months. Chronic $\mathrm{HCV}$ infection was confirmed by the presence of HCV RNA in blood tests. Cirrhosis was diagnosed by liver biopsy or based on clinical observations, laboratory tests or ultrasonographic evidence. Non-infected subjects were recruited from a group of healthy blood donors at the Public Blood Bank of Mato Grosso State. The absence of infection in the control group was confirmed by laboratory tests. Information about alcohol consumption, tobacco use, ethnicity and age was obtained from medical records and from an interviewer-administered questionnaire, which also included questions about exposure to mutagens and any history of cancer in the individual.

Cytokinesis-block MNs (CBMN) assay - The CBMN assay was performed as described by Fenech and Morley (1985), with minor modifications. In total, $5 \mu \mathrm{L}$ of venous blood was collected in heparin-Vacutainer tubes (Becton \& Dickinson, Franklin Lakes, NJ, USA) and lymphocyte cultures ( 2 per subject) were established using $0.3 \mathrm{~mL}$ of whole blood added to RPMI-1640 medium (Sigma-Aldrich, St. Louis, MO, USA) supplemented with $20 \%$ foetal calf serum (Cultilab, Campinas, SP, Brazil), $0.001 \%$ penicillin (Vetec, Duque de Caxias, RJ, Brazil), $0.0005 \%$ streptomycin (Sigma-Aldrich) and 2\% phytohemagglutinin (Cultilab). After the cultures were incubated for $44 \mathrm{~h}$ at $37^{\circ} \mathrm{C}$ in a BOD incubator (Eletrolab, São Paulo, SP, Brazil), cytochalasin B (Sigma-Aldrich) was added to the cultures $(6 \mu \mathrm{g} / \mathrm{mL})$. The cells were harvested by centrifugation at $72 \mathrm{~h}$ after the culture was initiated. The lymphocytes were treated with a hypotonic solution ( $1 \%$ sodium citrate $w / v)$ and fixed in a solution of methanol:acetic acid $(3: 1 \mathrm{v} / \mathrm{v})$; in both cases, the solutions were ice cold and freshly prepared. The cell suspension was dropped onto a pre-cooled microscope slide and air dried before being stained for 5-7 min with $5 \%$ Giemsa in Sorensen phosphate buffer $(0.06$ $\mathrm{M} \mathrm{Na}_{2} \mathrm{HPO}_{4}$ and $0.06 \mathrm{M} \mathrm{KH}_{2} \mathrm{PO}_{4}, \mathrm{pH}$ 6.8). Microscopic analysis was performed with a light microscope (Nikon, Melville, NY, USA) at 400X magnification. For each individual, 2,000 binucleated cells were analysed for the presence of MN, NPBs and NBUDs in accordance with previously established criteria (Fenech et al. 2003). We calculated the frequency of each biomarker (number in 1,000, \%) using the following formula: \%o of $\mathrm{X}=$ (number of $X / 2,000$ ) $x 1,000$, where $X$ is MN, NPBs or NBUDs (Montero et al. 2006).

Mutagen sensitivity evaluation - To determine mutagen sensitivity, the well-established mutagen DXR was used to treat lymphocytes from patients and noninfected subjects at $44 \mathrm{~h}$ after the culture was initiated. The cells were treated with $0.15 \mu \mathrm{g} / \mathrm{mL}$ DXR (Bergamo,
Taboão da Serra, SP, Brazil) diluted in sterile distilled water for $28 \mathrm{~h}$, which brought the total culture time to 72 h. The experimental conditions for the DXR treatment were previously established in preliminary experiments. The conditions for cell harvesting and slide preparation were described in the previous section. Sensitivity to DXR was expressed as induced DNA damage: [(mean MN after DXR)-(basal mean MN)].

Statistical analysis - An age comparison between groups was performed using one-way ANOVA and the Bonferroni post-hoc test. When the data exhibited unequal variance, the median numbers of MN, NPBs and NBUDs were compared between the groups using the non-parametric Kruskal-Wallis test followed by Dunn's post-hoc test. Similarly, the median numbers of $\mathrm{MN}$ obtained in the mutagen sensitivity test were compared between the groups using the Mann-Whitney $U$ test. The mean measurements of the induced DNA damage were compared using the Student's $t$ test. The G-test or the $\chi^{2}$ test was used to compare ethnicity, sex, alcohol intake and tobacco intake between the groups. A linear regression model was constructed using the Stata 8.2 software programme (StataCorp, College Station, TX, USA) to verify the independence of the frequencies of MN, NPBs and NBUDs from the virus type, sex, age, alcohol intake, tobacco intake and the use of antiviral drugs. A value of $p \leq 0.05$ was used as the criterion for significance. The statistical analyses were performed using the statistical software programme Bioestat 5.0 (Ayres et al. 2012).

Ethics - This study was approved by the Ethical Research Board of Julio Muller Hospital (protocol 439/ CEP-HUJM/07) and informed consent to voluntarily participate was given by all of the subjects.

\section{RESULTS}

Of the 49 patients included in the study, 28 were chronically infected with HBV (21 males and 7 females) and had a mean age of 36.1 years (ranging from 21-56 years), while 21 were chronically infected with HCV (13 males and 8 females) and had a mean age of 44.1 years (ranging from 27-55 years). The non-infected control group consisted of 23 males and 10 females with a mean age of 37.4 years (ranging from 20-52 years). No differences were observed between the non-infected group and the HBV or HCV-infected patients with regard to their sex $(p=0.97)$ and smoking habits $(p=0.16)$. The mean age was similar between the infected patients and the non-infected control subjects; however, the mean age of the HCV-infected patients was significantly higher than that of either the chronically HBV-infected group or the controls $(p<0.05)$. Alcohol consumption among the study subjects ranged from $0-8 \mathrm{~g} /$ day and was more frequently reported by the non-infected control subjects $(45.45 \%)$ than by the HBVinfected patients $(17.86 \%)$ or the HCV-infected patients $(14.28 \%)(p=0.003)$. Cirrhosis was present in eight HBVinfected patients $(28.6 \%)$ and three HCV-infected patients $(14.29 \%)(\mathrm{p}=0.31)($ Table I). All patients with cirrhosis were males. Seven patients (6 HBV-infected and $2 \mathrm{HCV}$ infected patients) were undergoing antiviral therapy at the time of the study (1 lamivudine and tenofovir, 2 ribavirin and $\alpha$-interferon and 3 tenofovir). 


\section{TABLE I}

Demographic and clinical characteristics of patients chronically infected with hepatitis B virus (HBV) or hepatitis $\mathrm{C}$ virus (HCV) and of control subjects

\begin{tabular}{|c|c|c|c|c|}
\hline $\begin{array}{l}\text { Demographic and } \\
\text { clinical parameters }\end{array}$ & $\begin{array}{c}\text { Controls } \\
(\mathrm{n}=33) \\
\mathrm{n}(\%)\end{array}$ & $\begin{array}{l}\text { Total patients } \\
\qquad(\mathrm{n}=49) \\
\mathrm{n}(\%)\end{array}$ & $\begin{array}{c}\text { HBV } \\
(\mathrm{n}=28) \\
\mathrm{n}(\%)\end{array}$ & $\begin{array}{c}\mathrm{HCV} \\
(\mathrm{n}=21) \\
\mathrm{n}(\%)\end{array}$ \\
\hline Males & $23(69.7)$ & $36(69.4)$ & $21(75)$ & $13(61.9)$ \\
\hline Females & $10(30.3)$ & $15(30.6)$ & $7(25)$ & $8(38.1)$ \\
\hline $\begin{array}{c}\text { Age (years) } \\
\text { Range }\end{array}$ & $\begin{array}{c}37.4 \pm 10.4 \\
(20-52)\end{array}$ & $\begin{array}{c}37.4 \pm 10.3 \\
(20-55)\end{array}$ & $\begin{array}{c}36.1 \pm 10.36^{a} \\
(27-55)\end{array}$ & $\begin{array}{c}37.41 \pm 7.7 \\
(20-52)\end{array}$ \\
\hline Smoking habit & $1(3.03)$ & $8(16.3)$ & $4(14.3)$ & $4(19.04)$ \\
\hline Alcohol consumption & $15(45.4)^{b}$ & $8(16.3)$ & $5(17.9)$ & $3(14.3)$ \\
\hline Cirrhosis & - & $11(22.4)$ & $8(28.6)$ & $3(14.3)$ \\
\hline
\end{tabular}

$a$ : ANOVA and Bonferroni post-hoc test, $\mathrm{p}<0.05 ; b$ : G test, $\mathrm{p}=0.004$.

The numbers of MN, NPBs and NBUDs observed in the patient group were $7.01 \pm 3.23,2.76 \pm 2.08$ and 4.57 \pm 2.98 , respectively. The frequencies of $\mathrm{MN}$ and NPBs, but not NBUDs, were significantly increased $(\mathrm{p}<0.0001)$ compared with the frequencies in the controls $(4.41 \pm 2.15$ and $1.15 \pm 0.97$ for MN and NPBs, respectively, in the controls). Considering the HBV-infected patients and the $\mathrm{HCV}$-infected patients separately, the numbers of $\mathrm{MN}$ in the HBV-infected patients $(7.18 \pm 3.57)$ and HCV-infected patients $(6.78 \pm 2.80)$ were significantly higher than in the non-infected group $(4.41 \pm 2.15)(\mathrm{p}<0.0001)$. The numbers of NPBs and NBUDs in the HBV-infected patients (3.27 \pm 2.40 and $4.71 \pm 2.79$, respectively) and in patients infected with HCV $(2.09 \pm 1.33$ and $4.38 \pm 3.28$, respectively) were increased relative to those of the control group $(1.15 \pm 0.97$ and $2.98 \pm 1.31$, respectively). However, only the difference between the HBV-infected group and the control group was statistically significant $(\mathrm{p}=0.03)$ (Table II). The results were independent of age, sex, alcohol consumption, tobacco intake and the presence of cirrhosis for MN $(\mathrm{R}=0.22, \mathrm{p}=0.02)$, NPBs $(\mathrm{R}=0.23, \mathrm{p}<0.001)$ and NBUDs $(R=0.15, p=0.03)$. The antiviral therapy did not significantly influence any of the analysed parameters. The frequency of $\mathrm{MN}$ was significantly influenced by sex only for males aged $<40$ years in the control group, who showed a significantly lower frequency of MN (3.46 $\pm 1.12)$ than did females $(5.63 \pm 1.60)$ of the same age $(\mathrm{p}$ $=0.01)$. The frequency of MN and NPBs was significantly higher in males, among all patients and within the HBV-infected group in comparison with the controls ( $\mathrm{p}$ $<0.01$ ) (Table III). The frequency of NPBs was significantly higher in females aged $>40$ years in comparison with the controls $(p<0.01)$. The frequency of MN, NPBs and NBUDs was not significantly higher in male patients with cirrhosis in comparison with male patients without cirrhosis (Table IV).

Cells from 15 chronically infected patients (9 HBV-infected and $6 \mathrm{HCV}$-infected patients) and 14 non-infected individuals were tested for DXR sensitivity. The numbers of MN were not significantly different between the HCVinfected and the HBV-infected patients; therefore, the patients were grouped together for comparison with the
TABLE II

Frequency of micronucleus (MN), nucleoplasmatic bridges (NPB) and nuclear buds (NBUDs) in hepatitis B virus (HBV) or hepatitis $\mathrm{C}$ virus (HCV)-infected patients and controls

\begin{tabular}{lccc}
\hline Groups & $\begin{array}{c}\text { MN } \\
(\text { mean } \pm \text { SD) }\end{array}$ & $\begin{array}{c}\text { NPB } \\
(\text { mean } \pm \text { SD) }\end{array}$ & $\begin{array}{c}\text { NBUDs } \\
(\text { mean } \pm \text { SD) }\end{array}$ \\
\hline Controls $(\mathrm{n}=33)$ & $4.41 \pm 2.15$ & $1.15 \pm 0.97$ & $2.98 \pm 1.31$ \\
Total patients $(\mathrm{n}=49)$ & $7.01 \pm 3.23^{a}$ & $2.76 \pm 2.08^{a}$ & $4.57 \pm 2.98$ \\
HBV $(\mathrm{n}=28)$ & $7.18 \pm 3.57^{a}$ & $3.27 \pm 2.40^{a}$ & $4.71 \pm 2.79^{b}$ \\
HCV $(\mathrm{n}=21)$ & $6.78 \pm 2.80^{a}$ & $2.09 \pm 1.33$ & $4.38 \pm 3.28$ \\
\hline
\end{tabular}

$a, b$ : statistically significant in comparison to the controls $(a: \mathrm{p}$ $<0.0001 ; b$ : $\mathrm{p}=0.03$; Kruskal-Wallis test with Dunn's post-hoc test); SD: standard deviation..

non-infected individuals to improve the statistical analysis. The patients exhibited significantly higher numbers of MN in both untreated $(6.76 \pm 3.03, p=0.03)$ and treated $(15.03 \pm 4.94, p=0.001)$ cells compared with the cells of non-infected individuals $(4.25 \pm 1.45$ and $9.39 \pm 3.39$ in untreated and treated cells, respectively). DXR treatment significantly increased the number of MN in both the control group $(p=0.0002)$ and the patient group $(p<0.0001)$. The mean measurements of the induced DNA damage were higher in the patient group $(8.30 \pm 5.40)$ than in the non-infected control group $(5.18 \pm 3.45)$. However, this difference was not found to be statistically significant, which was possibly due to a type 2 error $(\mathrm{p}=0.06)$.

\section{DISCUSSION}

Chronic hepatotropic virus (HBV and HCV) infections are characterised by potentially mutagenic cellular events, such as an increase in oxidative stress and viral integration into the DNA of the host cell (Farinati et al. 1995, Bartsch \& Nair 2004, Saigo et al. 2008, Sung et al. 2012). In the present study, we demonstrated that the lymphocytes of HBV-infected patients and HCV-infected patients exhibited an increased frequency of MN compared with lymphocytes from healthy, non-infected individuals. This result is in contrast to findings previ- 


\section{TABLE III}

The effect of age and sex on frequency of micronucleus (MN), nucleoplasmatic bridges (NPB) and nuclear buds (NBUDs) $n$ hepatitis B virus (HBV) or hepatitis $\mathrm{C}$ virus (HCV)-infected patients and controls

\begin{tabular}{|c|c|c|c|}
\hline Groups & $\begin{array}{c}\mathrm{MN} \\
(\text { mean } \pm \mathrm{SD})\end{array}$ & $\begin{array}{c}\text { NPB } \\
(\text { mean } \pm \text { SD) }\end{array}$ & $\begin{array}{c}\text { NBUDs } \\
(\text { mean } \pm \text { SD })\end{array}$ \\
\hline \multicolumn{4}{|l|}{ Controls $(n=33)$} \\
\hline Males $<40$ years $(n=14)$ & $3.46 \pm 1.12^{a}$ & $1.32 \pm 1.31$ & $2.86 \pm 2.67$ \\
\hline Males $\geq 40$ years $(n=9)$ & $4.06 \pm 1.59$ & $0.83 \pm 0.5$ & $2.67 \pm 1.17$ \\
\hline Females $<40$ years $(n=4)$ & $5.63 \pm 1.60$ & $1.50 \pm 0.82$ & $4.13 \pm 0.85$ \\
\hline Females $\geq 40$ years $(n=6)$ & $6.33 \pm 3.54$ & $1.0 \pm 0.63$ & $3.0 \pm 1.26$ \\
\hline \multicolumn{4}{|l|}{ Total patients $(\mathrm{n}=49)$} \\
\hline Males $<40$ years $(\mathrm{n}=14)$ & $6.79 \pm 4.49^{b}$ & $3.5 \pm 2.97^{b}$ & $4.03 \pm 2.45$ \\
\hline Males $\geq 40$ years $(n=20)$ & $7.25 \pm 2.92^{b}$ & $3.08 \pm 1.45^{b}$ & $5.10 \pm 3.72$ \\
\hline Females $<40$ years $(\mathrm{n}=6)$ & $6.92 \pm 2.85$ & $3.0 \pm 2.34$ & $4.0 \pm 2.61$ \\
\hline Females $\geq 40$ years $(n=9)$ & $6.89 \pm 2.10$ & $3.50 \pm 1.44^{b}$ & $4.61 \pm 2.25$ \\
\hline \multicolumn{4}{|l|}{$\operatorname{HBV}(\mathrm{n}=28)$} \\
\hline Males $<40$ years $(\mathrm{n}=12)$ & $6.71 \pm 4.82^{b}$ & $3.27 \pm 3.14^{b}$ & $4.42 \pm 2.45$ \\
\hline Males $\geq 40$ years $(n=9)$ & $7.33 \pm 2.03^{b}$ & $3.27 \pm 1.51^{b}$ & $5.89 \pm 3.46$ \\
\hline Females $<40$ years $(n=4)$ & $7.0 \pm 3.63$ & $3.25 \pm 2.96$ & $3.25 \pm 2.90$ \\
\hline Females $\geq 40$ years $(\mathrm{n}=3)^{c}$ & $8.83 \pm 1.53$ & $3.12 \pm 0.48$ & $4.33 \pm 0.76$ \\
\hline \multicolumn{4}{|l|}{$\operatorname{HCV}(\mathrm{n}=21)$} \\
\hline Males < 40 years $(\mathrm{n}=2)$ & $7.25 \pm 2.47$ & $5.0 \pm 0$ & $1.75 \pm 0.35$ \\
\hline Males $\geq 40$ years $(n=11)$ & $7.18 \pm 3.59^{b}$ & $2.67 \pm 1.37^{b}$ & $4.45 \pm 3.97$ \\
\hline Females $<40$ years $(\mathrm{n}=2)$ & $6.75 \pm 1.06$ & $2.50 \pm 0.71$ & $5.50 \pm 1.41$ \\
\hline Females $\geq 40$ years $(n=6)$ & $5.92 \pm 1.66$ & $3.80 \pm 1.92^{b}$ & $4.75 \pm 2.79$ \\
\hline
\end{tabular}

$a$ : statistically significant in comparison to females of the same age-class ( $\mathrm{p}=0.01$, Mann-Whitney $U$ test); $b$ : statistically significant in relationship to controls of the same age class $(\mathrm{p}<0.01$, ANOVA, post-test Student $t$ or Kruskal-Wallis, post test StudentNewman-Keuls); $c$ : groups with $\mathrm{n}<4$ were not included in statistical analysis; SD: standard deviation.

\section{TABLE IV}

The effect of cirrhosis on frequency of micronucleus (MN), nucleoplasmatic bridges (NPB) and nuclear buds (NBUDs) in males hepatitis B virus (HBV) or hepatitis $\mathrm{C}$ virus (HCV)infected patients

\begin{tabular}{lcccc}
\hline \multirow{4}{*}{ Groups } & $\begin{array}{c}\text { Cirrhosis } \\
(\mathrm{n})\end{array}$ & $\begin{array}{c}\text { MN } \\
(\text { mean } \pm \text { SD) }\end{array}$ & $\begin{array}{c}\text { NPB } \\
\text { Total patients } \pm \text { SD) }\end{array}$ & $\begin{array}{c}\text { NBUDs } \\
\text { mean } \pm \text { SD) }\end{array}$ \\
& No (23) & $6.82 \pm 4.10$ & $2.98 \pm 2.53$ & $3.67 \pm 1.75$ \\
HBV & Yes (11) & $7.54 \pm 2.27$ & $2.68 \pm 1.58$ & $5.00 \pm 2.59$ \\
& No (15) & $6.56 \pm 4.36$ & $3.26 \pm 2.91$ & $4.13 \pm 1.72$ \\
HCV & Yes (8) & $8.25 \pm 2.23$ & $3.06 \pm 1.68$ & $5.25 \pm 2.39$ \\
& No (9) & $7.31 \pm 3.80$ & $2.43 \pm 1.63$ & $2.81 \pm 1.53$ \\
& Yes (3) & $7.00 \pm 2.90$ & $1.66 \pm 0.76$ & $4.33 \pm 3.54$ \\
\hline
\end{tabular}

SD: standard deviation.

ously reported by Ozkal et al. (2005). However, these authors reported a higher frequency of chromosome breaks, leading to the formation of acentric chromosome/chromatid fragments that ultimately contributed to the formation of MN. Furthermore, the MN may have resulted from an inability of whole chromosomes to travel to the spindle poles during mitosis (Fenech et al. 2011). A higher frequency of chromosome gaps, aneuploidy and polyploidy in the peripheral blood mononuclear cells (PBMCs) of $\mathrm{HCV}$-infected patients was reported previously (Machida et al. 2010). The present results suggest that chronic infection with HBV or HCV accounts for chromosomal instability in lymphocytes and this phenomenon is characterised by the formation of acentric fragments and/or aneuploidy.

We also observed increased numbers of NPBs and NBUDs in HBV-infected patients. NPBs may occur when dicentric chromosomes originating from chromosome breaks or telomere-to-telomere end fusions are pulled to opposite poles of the cell during mitosis. NBUDs are primarily considered to be formed from amplified DNA that is being eliminated from chromosomes (Fenech et al. 2011). Although gene amplifications (MYC and $E R B B 2$ ) were demonstrated in HCC tissue samples that were infected with HBV or HCV (Al-Qahtani et al. 2010), no reports have described this genetic alteration in PBMCs from individuals with viral hepatitis. Dicentric $\mathrm{Y}$ chromosomes have also been reported in the PBMCs of HCV-infected patients (Machida et al. 2010). Together with our results, these data suggest that the chromosomal instability in lymphocytes that results from HBV infection (and likely also from chronic HCV infection) is characterised by the presence of dicentric chromosomes and gene amplification. 
In this study, females and subjects aged $\geq 40$ years exhibited more MN than did males and subjects $<40$ years, respectively, among both controls and HBV-infected patients. Although these differences were not statistically significant, the results are in accordance with the well-known influence of sex and age on MN frequencies, as reported before (Fenech 1998, Bonassi et al. 2001, Fenech \& Bonassi 2011). Reports on the effects of sex and age on NPBs and NBUDs are conflicting in the literature (Donmez-Altuntas \& Bitgen 2012, Nefic \& Handzic et al. 2013).

Considering the patient group, we found statistically significantly higher frequencies of $\mathrm{MN}$ in males than in females; however, females did not present cirrhosis in our sample. It is known that DNA damage levels in the leukocytes of HBV-infected patients and HCV-infected patients significantly correlate with the presence of liver lesions (Farinati et al. 1999, Cardin et al. 2001, Grossi et al. 2008, Hoare et al. 2013). In fact, in the current study, the frequencies of MN (in HBV-infected patients) and NBUDs (in HBV-infected patients and HCV-infected patients) were increased in cirrhotic males, but this difference was not significant. Whether the extension of liver lesions in male patients is correlated with the frequency of MN found in lymphocytes is not completely clear in the sample investigated here. Even considering that the statistical analysis may have been influenced by the small size of our sample, these results should be considered with caution, especially because chromosome damage detected by the MN assay is an important biomarker for cancer prediction (Bonassi et al. 2007).

HBV and HCV may contribute to increased chromosomal aberrations in infected cells by direct and indirect pathways. Regarding the indirect pathway, it has been shown that the presence of reactive oxygen species (ROS) resulting from cytokine activity during chronic inflammation has a potent mutagenic effect (Yan et al. 2006). A relationship between infection with HBV or $\mathrm{HCV}$ and increased production of ROS, chromosomal aberrations and other DNA damage has been reported previously (Hagen et al. 1994, Machida et al. 2010). Furthermore, leukocytes from patients who are chronically infected with HBV or HCV exhibit higher levels of 8 -OHdG, which is the most frequent ROS-induced base lesion (Farinati et al. 1999, Cardin et al. 2001).

Viral integration is considered to have direct mutagenic potential in hepatocytes. The integration of HBV into the human genome affects the expression of genes located near the site of insertion and also causes more widespread alterations of chromosomal stability (Saigo et al. 2008, Sung et al. 2012). Because viral genome integration into the host DNA also frequently occurs in the PBMCs of chronically HBV-infected patients (Murakami et al. 2004), this process may contribute to genomic instability in these cells. Recently, it was demonstrated that in chronic HCV infection, the presence of double strand breaks occurs concomitantly with shortened telomeres in $\mathrm{T}$ lymphocytes. This phenomenon is associated with the level of fibrosis and may influence the response to treatment (Hoare et al. 2013).

The frequency of mutations is directly influenced by the efficiency of the DNA repair mechanisms because failure to remove a lesion can facilitate mutational fixa- tion. Extensive evidence has demonstrated that proteins produced by HBV and $\mathrm{HCV}$ interact with the proteins of the DNA repair machinery and inhibit their functions in host cells (Chen et al. 2008, Machida et al. 2010, Pal et al. 2010). Therefore, it is possible that the cells of infected patients exhibit less efficient DNA repair mechanisms due to the effects of the viral proteins, which may contribute to the elevated frequency of DNA damage detected in this study.

Au et al. (2010) reported that when the cells of exposed populations (in this case, HCV-infected patients or HBVinfected patients) are challenged with a DNA-damaging agent in vitro, the in vivo exposure-induced repair deficiency is dramatically amplified. Additionally, the deficiency will be detectable in a challenge assay as an increase in the number of chromosomal aberrations, $\mathrm{MN}$ or unrepaired DNA strand breaks.

Less effective DNA repair may also result in a higher sensitivity to mutagens. It has been shown that B lymphocytes infected with HCV in vitro exhibit increased sensitivity to bleomycin due to the action of the NS3 protein and the core viral protein (Machida et al. 2010). Furthermore, it was demonstrated that lymphocytes from HBV or $\mathrm{HCV}$-infected HCC patients exhibit an increased sensitivity to bleomycin and benzo(a)pyrene-diol-epoxide, which is associated with an increased risk of cancer development (Wu et al. 1998). The results obtained in the present study showed that the lymphocytes of HBV-infected patients and $\mathrm{HCV}$-infected patients are not more sensitive to DXR than the lymphocytes of non-infected subjects. However, a challenge assay with other substances, such as bleomycin, needs to be performed to allow more definite conclusions about mutagen sensitivity in these patients.

In summary, the present study demonstrated that the lymphocytes of patients who are chronically infected with HBV or HCV exhibit greater chromosomal instability, characterised by the presence of MN, NPBs and NBUDs. Although we did not observe a statistically significant result, a possible influence of cirrhosis on these parameters should be considered for further investigation.

\section{ACKNOWLEDGEMENTS}

To Gevanil Arruda, Nilson Santana Botelho and Maria Celina da Penha, for providing technical assistance.

\section{REFERENCES}

Al-Qahtani A, Al-Hazzani T, Al-hussain T, Al-Ghamdi A, Al-Mana H, Al-Arifi S, Al-Ahdal M, Aly M 2010. Correlation between clinical characteristics, survival and genetic alterations in patients with hepatocellular carcinoma from Saudi Arabia. Cancer Genet Cytogenet 203: 269-277.

Au WW, Giri AK, Ruchirawat M 2010 Challenge assay: a functional biomarker for exposure-induced DNA repair deficiency and for risk cancer. Int J Hyg Environ Health 213: 32-39.

Ayres M, Ayres Jr M, Ayres DL, dos Santos AAS 2012. BioEstat 5.0. Available from: mamiraua.gov.br.

Bonassi S, Fenech M, Lando C, Lin YP, Ceppi M, Chang WP, Holland N, Kirsch-Volders M, Zeiger E, Ban S, Barale R, Bigatti MP, Bolognesi C, Jia C, Di Giorgio M, Ferguson LR, Fucic A, Lima OG, Hrelia P, Krishnaja AP, Lee TK, Migliore L, Mikhalevich L, Mirkova E, Mosesso P, Müller WU, Odagiri Y, Scarffi MR, Szabova E, Vorobtsova I, Vral A, Zijno A 2001. HUman MicroNucleus project: international database comparison for 
results with the cytokinesis-block micronucleus assay in human lymphocytes: I. Effect of laboratory protocol, scoring criteria and host factors on the frequency of micronuclei. Environ Mol Mutagen 37: 31-45.

Bonassi S, Znaor A, Ceppi M, Lando C, Chang WP, Holland N, Kirsch-Volders M, Zeiger E, Ban S, Barale R, Bigatti MP, Bolognesi C, Cebulska-Wasilewska A, Fabianova E, Fucic A, Hagmar L, Joksi EG, Martelli A, Migliore L, Mirkova E, Scarfi MR, Zijno A, Norppa H, Fenech M 2007. An increased micronucleus frequency in peripheral blood lymphocytes predicts the risk of cancer in humans. Carcinogenesis 28: 625-631.

Cardin R, Saccoccio G, Masutti F, Bellentani S, Farinati F, Tiribelli C 2001. DNA oxidative damage in leukocytes correlates with the severity of HCV-related liver disease: validation in an open population study. J Hepatol 34: 587-592.

Chen HY, Tang NH, Lin N, Chen ZX, Wang XZ 2008. Hepatitis B virus $\mathrm{X}$ protein induces apoptosis and cell cycle deregulation through interfering with DNA repair and checkpoint responses. Hepatol Res 38: 174-182.

Donmez-Altuntas H, Bitgen N 2012. Evaluation of the genotoxicity and cytotoxicity in the general population in Turkey by use of the cytokinesis-block micronucleus cytome assay. Mutat Res 748: 1-7.

Farinati F, Cardin R, De Maria N, Della Libera G, Marafin C, Lecis E, Burra P, Floreani A, Cecchetto A, Naccarato R 1995. Iron storage, lipid peroxidation and glutathione turnover in chronic antiHCV positive hepatitis. J Hepatol 22: 449-456.

Farinati F, Cardin R, Degan P, De Maria N, Floyd RA, Van Thiel DH, Naccarato R 1999. Oxidative DNA damage in circulating leukocytes occurs as an early event in chronic HCV infection. Free Radic Biol Med 27: 1284-1291.

Fenech M 1998. Important variables that influence base-line micronucleus frequency in cytokinesis-blocked lymphocytes-a biomarker for DNA damage in human populations. Mutat Res 404: 155-165.

Fenech M, Bonassi S 2011. The effect of age, gender, diet and lifestyle on DNA damage measured using micronucleus frequency in human peripheral blood lymphocytes. Mutagenesis 26: 43-49.

Fenech M, Chang WP, Kirsch-Volders M, Holland N, Bonassi S, Zeiger E 2003. HUman MicroNucleus project. HUMN project: detailed description of the scoring criteria for the cytokinesisblock micronucleus assay using isolated human lymphocyte cultures. Mutat Res 534: 65-75.

Fenech M, Kirsch-Volders M, Natarajan AT, Surralles J, Crott JW, Parry J, Norppa H, Eastmond DA, Tucker JD, Thomas P 2011. Molecular mechanisms of micronucleus, nucleoplasmic bridge and nuclear bud formation in mammalian and human cells. $\mathrm{Mu}$ tagenesis 26: 125-132.

Fenech M, Morley A 1985. Solutions to the kinetic problem in the micronucleus assay. Cytobios 43: 233-246.

Grossi S, Sumberaz A, Gosmar M, Mattioli F, Testino G, Martelli A 2008. DNA damage in peripheral blood lymphocytes of patients with cirrhosis related to alcohol abuse or to hepatitis B and C viruses. Eur J Gastroenterol Hepatol 20: 22-25.

Hagen TM, Huang S, Curnutte J, Fowler P, Martinez V, Wehr CM, Ames BN, Chisari FV 1994. Extensive oxidative DNA damage in hepatocytes of transgenic mice with chronic active hepatitis destined to develop hepatocellular carcinoma. Proc Natl Acad Sci USA 91: 12808-12812.

Heijink AM, Krajewska M, van Vugt MA 2013. The DNA damage response during mitosis. Mutat Res 750: 45-55.

Hoare M, Shankar A, Shah M, Rushbrook S, Gelson W, Davies S, Akbar A, Alexander GJ 2013. $\gamma-\mathrm{H} 2 \mathrm{AX}^{+} \mathrm{CD} 8^{+} \mathrm{T}$ lymphocytes can- not respond to IFN- $\alpha$, IL-2 or IL-6 in chronic hepatitis $\mathrm{C}$ virus infection. J Hepatol 58: 868-874.

Huang B, Li J, Zhou Z, Zheng D, Liu J, Chen M 2012. High prevalence of hepatitis B virus infection in multiple myeloma. Leuk Lymphoma 53: 270-274.

Jackson SP, Bartek J 2009. The DNA-damage response in human biology and disease. Nature 461: 1071-1078.

Machida K, McNamara G, Cheng KT, Huang J, Wang CH, Comai L, Ou JH, Lai MM 2010. Hepatitis C virus inhibits DNA damage repair through reactive oxygen and nitrogen species and by interfering with the ATM-NBS1/Mre11/Rad50 DNA repair pathway in monocytes and hepatocytes. J Immunol 185: 6985-6998.

Montero R, Serrano L, Araujo A, Dávila V, Ponce J, Camacho R, Morales E, Méndez A 2006. Increased cytogenetic damage in a zone in transition from agricultural to industrial use: comprehensive analysis of the micronucleus test in peripheral blood lymphocytes. Mutagenesis 21: 335-342.

Murakami Y, Minami M, Daimon Y, Okanoue T 2004. Hepatitis B virus DNA in liver, serum and peripheral blood mononuclear cells after the clearance of serum hepatitis B virus surface antigen. J Med Virol 72: 203-214.

Nefic H, Handzic I 2013. The effect of age, sex and lifestyle factors on micronucleus frequency in peripheral blood lymphocytes of the Bosnian population. Mutat Res 753: 1-11.

Ozkal P, Ilgin-Ruhi H, Akdogan M, Elhan AH, Kaçar S, Sasmaz N 2005. The genotoxic effects of hepatitis B virus to host DNA. Mutagenesis 20: 147-150.

Pal S, Polyak SJ, Bano N, Qiu WC, Carithers RL, Shuhart M, Gretch DR, Das A 2010. Hepatitis C virus induces oxidative stress, DNA damage and modulates the DNA repair enzyme NEIL1. J Gastroenterol Hepatol 25: 627-634.

Saigo K, Yoshida K, Ikeda R, Sakamoto Y, Murakami Y, Urashima T, Asano T, Kenmochi T, Inoue I 2008. Integration of hepatitis B virus DNA into the myeloid/lymphoid or mixed-lineage leukemia (MLL4) gene and rearrangements of MLL4 in human hepatocellular carcinoma. Hum Mutat 29: 703-708.

Sung WK, Zheng H, Li S, Chen R, Liu X, Li Y, Lee NP, Lee WH, Ariyaratne PN, Tennakoon C, Mulawadi FH, Wong KF, Liu AM, Poon RT, Fan ST, Chan KL, Gong Z, Hu Y, Lin Z, Wang G, Zhang Q, Barber TD, Chou WC, Aggarwal A, Hao K, Zhou W, Zhang C, Hardwick J, Buser C, Xu J, Kan Z, Dai H, Mao M, Reinhard C, Wang J, Luk JM 2012. Genome-wide survey of recurrent HBV integration in hepatocellular carcinoma. Nat Genet 44: 765-769.

Szabó E, Páska C, Kaposi Novák P, Schaff Z, Kiss A 2004. Similarities and differences in hepatitis B and C virus induced hepatocarcinogenesis. Pathol Oncol Res 10: 5-11.

Wu X, Gu J, Patt Y, Hassan M, Spitz MR, Beasley RP, Hwang LY 1998. Mutagen sensitivity as a susceptibility marker for human hepatocellular carcinoma. Cancer Epidemiol Biomarkers Prev 7: 567-570.

Wu X, Gu J, Spitz MR 2007. Mutagen sensitivity: a genetic predisposition factor for cancer. Cancer Res 67: 3493-3495.

Yan B, Wang H, Rabbani ZN, Zhao Y, Li W, Yuan Y, Li F, Dewhirst MW, Li CY 2006. Tumor necrosis factor-alpha is a potent endogenous mutagen that promotes cellular transformation. Cancer Res 66: 11565-11570.

Zuckerman E, Zuckerman T, Levine AM, Douer D, Gutekunst K, Mizokami M, Qian DG, Velankar M, Nathwani BN, Fong TL 1997. Hepatitis $\mathrm{C}$ virus infection in patients with B-cell non-Hodgkin lymphoma. Ann Intern Med 127: 423-428. 